\title{
ANALISIS EMERGENCY RESPONSE PLAN (ERP) PADA KEGIATAN PRAKTEK TERBANG TARUNA JURUSAN PENERBANG SEKOLAH TINGGI PENERBANGAN INDONESIA CURUG
}

\author{
Surya Tri Saputra \\ Politeknik Penerbangan Indonesia Curug \\ e-mail: suryaatc12@gmail.com
}

\begin{abstract}
Abstrak: Praktik terbang merupakan kegiatan yang memiliki potensi risiko besar sehingga dapat menimbulkan dampak negatif, seperti hilangnya materi, nyawa manusia, dan reputasi sebuah instansi. Ketika risiko tersebut tidak dapat terhindar maka diperlukan Emergency Response Plan (ERP) sebagai sebuah panduan organisasi untuk menghadapi situasi darurat. Penelitian yang dilakukan pada tahun 2017 ini bertujuan untuk menganalisa panduan Emergency Response Plan (ERP) khususnya dalam pelaksanaan praktik terbang taruna di Jurusan Penerbang - Sekolah Tinggi Penerbangan Indonesia Curug. Dalam penelitian ini penulis menggunakan metode gap analisis untuk mengetahui kesenjangan antara kondisi ideal dengan kondisi eksisting berdasarkan Doc. 9859 Safety Management Manual. Tahapan dalam penelitian ini yaitu melakukan literatur study, membuat gap analisis, melakukan identifikasi dan penilaian potensi risiko yang mungkin terjadi dan melakukan reviu serta validasi dokumen. Penelitian ini menyimpulkan bahwa Emergency Response Plan (ERP) Manual dibutuhkan penyempurnaan dan perlu dilakukan simulasi penanganan keadaan darurat.
\end{abstract}

Kata Kunci: Emergency Response Plan, Safety Management System, hazard identification, mitigation, risk assessment.

Abstract: $\quad$ The practice of flying is an activity that has a high potential risk of causing negative impacts, such as loss of material, human life and reputation of an agency. When these risks cannot be avoided, an Emergency Response Plan (ERP) is needed as an organizational guide for dealing with emergency situations. This study, which was conducted in 2017, aims to analyze the Emergency Response Plan (ERP) guidelines, especially in the implementation of cadets' flying practices in the Aviation Department Indonesian Civil Aviation Institute Curug. In this study, the authors used the gap analysis method to determine the gap between ideal conditions and existing conditions based on Doc. 9859 Safety Management Manual. The stages in this research are conducting a literature study, making gap 
analysis, identifying and assessing potential risks that may occur and conducting a review and validation of documents. This study concludes that the Emergency Response Plan (ERP) Manual is required to be refined and an emergency handling simulation is needed.

Keyword: $\quad$ Emergency Response Plan, Safety Management System, hazard identification, mitigation, risk assessment.

\section{Pendahuluan}

Dunia Penerbangan tidak lepas dari konsekuensi atau resiko dari setiap aktivitas yang dilakukan dalam operasi penerbangan. Oleh karena itu, perlu dilakukan identifikasi dan pengelolaan potensi risiko agar dapat diantisipasi. Dengan mengetahui sumber risiko sejak dini maka potensi risiko tersebut dapat dikelola dengan sebaik-baiknya sehingga tidak menimbulkan kerusakan material, hilangnya nyawa manusia, dan reputasi buruk organisasi penerbangan. Untuk mengendalikan potensi risiko diperlukan Safety Management System (SMS).

SMS diperlukan bagi organisasi penerbangan untuk mengidentifikasi bahaya dan mengelola risiko keselamatan yang dihadapi selama pengiriman produk atau layanannya. Dasar-dasar Sistem Manajemen Keselamatan adalah Identifikasi bahaya keselamatan, memastikan bahwa tindakan perbaikan yang diperlukan untuk mempertahankan tingkat keselamatan yang dapat diterima dilaksanakan, menyediakan pemantauan berkelanjutan dan penilaian rutin tingkat keselamatan yang dicapai, dan bertujuan untuk melakukan perbaikan terus-menerus pada tingkat keseluruhan keamanan. ((Doc. 9859
Safety Management Manual (SMM): 2013).

Dengan SMS, potensi bahaya dan risiko yang mungkin terjadi dapat dikelola dan diawasi dengan baik. Meski telah dilakukan dengan benar, namun kecelakaan masih dimungkinkan terjadi karena beberapa faktor yang tidak terduga dan kemampuan manusia. Ketika risiko tinggi gagal mencegah kecelakaan atau kejadian, upaya yang paling mungkin dilakukan adalah mengelola situasi darurat untuk mengurangi keparahan kasus.

Safety Management System (SMS) mengharuskan setiap penyedia layanan untuk membuat dan memelihara rencana tanggap darurat untuk kecelakaan dan insiden dalam pengoperasian pesawat terbang dan keadaan darurat penerbangan lainnya. Penyedia layanan harus memastikan bahwa rencana tanggap darurat dikoordinasikan dengan benar dengan rencana tanggap darurat dari organisasi yang harus berinteraksi dengannya selama penyediaan produk dan layanannya. Penanganan keadaan darurat perlu didokumentasikan dalam Emergency Renspon Plan (ERP) Manual. ((Doc. 9859 Safety Management Manual (SMM): 2013). 
Analisis Emergency Response Plan (ERP) pada Kegiatan Praktek Terbang Taruna Jurusan Penerbang Sekolah Tinggi Penerbangan Indonesia Curug

Emergency Renspon Plan (ERP) menguraikan secara tertulis apa yang harus dilakukan setelah kecelakaan atau krisis penerbangan dan siapa yang bertanggung jawab untuk setiap tindakan. Rencana Tanggap Darurat (ERP) akan diaktifkan secara otomatis selama kecelakaan dan insiden dalam operasi pesawat atau krisis manajemen lainnya. Berdasarkan Staff Instruction (SI) 19 - 05 tentang Safety Management System (SMS), tujuan dari ERP adalah untuk:

a. Memastikan bahwa ada transisi yang teratur dan efisien dari operasi normal ke darurat, termasuk penugasan tanggung jawab darurat dan pendelegasian wewenang. Otorisasi untuk tindakan oleh personel kunci juga tercantum dalam rencana, serta sarana untuk mengoordinasikan upaya yang diperlukan untuk mengatasi keadaan darurat.

b. Tujuan keseluruhannya adalah untuk menyelamatkan nyawa, kelangsungan operasi yang aman, dan kembali ke operasi normal secepat mungkin.

Pada tahun 2010, Sekolah Tinggi Penerbangan Indonesia Curug mengalami dua kecelakaan fatal: pesawat latih menabrak dua kendaraan sepeda motor saat mendarat di Bandara Budiarto dan jatuhnya pesawat latih di Selat Sunda saat melakukan lintas alam dari Bandara Raden Inten II, Lampung menuju Bandara Budiarto, Curug. Pada saat terjadi kecelakaan pesawat, seharusnya ERP sudah mulai diaktifkan, namun manual ERP yang ada pada Jurusan Penerbang Polteknik Penerbangan Indonesia hanya berfungsi sebagian dan sejak awal terbentuknya manual ERP belum pernah ditinjau ulang terkait unit-unit yang berperan dalam penanganan keadaaan darurat. Dengan beberapa kasus yang telah dialami, Sekolah Tinggi Penerbangan Indonesia Curug berusaha untuk dapat melakukan perbaikan - perbaikan dalam menghadapi situasi krisis.

\section{Metode}

Dalam Penelitian ini, penulis menggunakan gap analisis untuk mengetahui kondisi ideal dengan kondisi eksisting berdasarkan Doc. 9859 Safety Management Manual.

Selanjutnya seteleh mengetahui gap (kesenjangan), penulis melakukan branstroming terkait dengan potensi

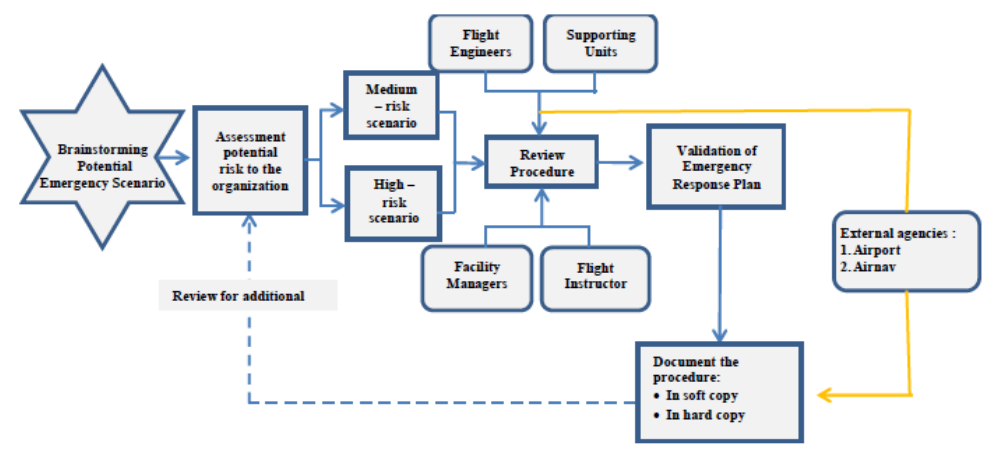

Gambar 1 
kejadian emergency. Metodelogi dan data proses dapat digambarkan sebagai berikut:

a. Brainstorming tentang potensi situasi darurat yang mungkin terjadi. Untuk mengetahui situasi darurat potensial.

b. Penilaian potensi risiko bagi organisasi mengacu pada dokumen Safety Management System Manual Jurusan Penerbang. Peneliti akan melakukan brainstorming dengan instruktur penerbang dan dan unit penunjang di Jurusan Penerbang.

c. Melakukan tinjauan terhadap Emergency Response Plan Manual berdasarkan hasil gap analisis. d. Merevisi Emergency Response Plan Manual dengan melibatkan instruktur penerbang, teknisi penerbang serta dari lembaga eksternal.

e. Validasi dilaksanakan dengan melakukan meeting review dengan pihak manajemen dari Jurusan Penerbang Sekolah Tinggi Penerbangan Indonesia Curug.

\section{Diskusi}

Gap analisis dilakukan dengan menggunakan indikator - indikator yang telah ditetukan dalam Doc. 9859 Safety Management Manual. Hasil dari gap analisis dapat dilihat pada tabel 1 sebagai berikut:

Tabel 1

\begin{tabular}{|c|c|c|c|c|}
\hline No & Area & Hasil Gap Analisis & $\begin{array}{c}\text { Rencana Tindak } \\
\text { Lanjut }\end{array}$ & Output \\
\hline 1 & $\begin{array}{l}\text { Governing } \\
\text { Policies }\end{array}$ & $\begin{array}{lll}\text { a. } & \text { Kesepakatan dengan } & \text { otoritas } \\
& \text { lokal belum ada } & \\
\text { b. } & \begin{array}{l}\text { Kebijakan dan } \\
\text { perusahaan belum ada }\end{array} & \text { prioritas } \\
\end{array}$ & $\begin{array}{ll}\text { a. } & \begin{array}{l}\text { Koordinasi dengan } \\
\text { otoritas setempat } \\
\text { dan pembuatan }\end{array} \\
\text { Letter of } \\
\text { Agreement } \\
\text { b. } & \text { Tinjau ulang } \\
& \text { Emergency } \\
\text { Response Plan } & \text { Manual } \\
\end{array}$ & $\begin{array}{l}\text { Letter of } \\
\text { Agreement, } \\
\text { ERP } \\
\text { Manual }\end{array}$ \\
\hline 2 & Organization & $\begin{array}{ll}\text { a. } & \text { Peran dan tanggung jawab } \\
\text { personel dalam ERP masih } \\
\text { secara umum, tidak ada tugas } \\
\text { yang jelas dari setiap personal } \\
\text { b. } \\
\text { Tidak ada prosedur dalam } \\
\text { memperjelas jalur pelaporan } \\
\text { c. Alur aktivasi Rencana Tanggap } \\
\text { d. Darurat belum ditentukan } \\
\text { Belum ada penunjukan juru } \\
\text { bicara dalam menangani media } \\
\text { e. Otoritas keuangan dalam hal } \\
\text { ERP belum dijelaskan }\end{array}$ & $\begin{array}{lr}\text { Tinjau } & \text { ulang } \\
\text { Emergency } & \text { Response } \\
\text { Plan Manual } & \end{array}$ & $\begin{array}{l}\text { ERP } \\
\text { Manual }\end{array}$ \\
\hline 3 & $\begin{array}{l}\text { Initial } \\
\text { Response }\end{array}$ & 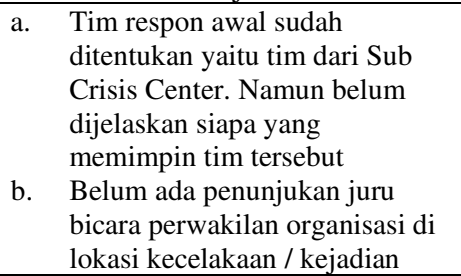 & $\begin{array}{lr}\text { Tinjau } & \text { ulang } \\
\text { Emergency } & \text { Response } \\
\text { Plan Manual } & \end{array}$ & $\begin{array}{l}\text { ERP } \\
\text { Manual }\end{array}$ \\
\hline
\end{tabular}


Analisis Emergency Response Plan (ERP) pada Kegiatan Praktek Terbang Taruna Jurusan Penerbang Sekolah Tinggi Penerbangan Indonesia Curug

\begin{tabular}{|c|c|c|c|c|}
\hline No & Area & Hasil Gap Analisis & $\begin{array}{c}\text { Rencana Tindak } \\
\text { Lanjut }\end{array}$ & Output \\
\hline 4 & $\begin{array}{l}\text { Emergency } \\
\text { Management } \\
\text { Center }\end{array}$ & $\begin{array}{l}\text { a. } \begin{array}{l}\text { Pusat tanggap darurat belum } \\
\text { dijelaskan terkait dengan } \\
\text { kebutuhan peralatan }\end{array} \\
\text { komunikasi, dokumentasi, dan } \\
\text { perlengkapan kantor. } \\
\text { b. Pemeriksaan catatan perusahaan } \\
\text { terkait belum dijelaskan } \\
\text { c. Referensi dokumen belum } \\
\text { dijelaskan }\end{array}$ & $\begin{array}{lr}\text { Tinjau } & \text { ulang } \\
\text { Emergency } & \text { Response } \\
\text { Plan Manual } & \end{array}$ & $\begin{array}{l}\text { ERP } \\
\text { Manual }\end{array}$ \\
\hline 5 & News Media & $\begin{array}{l}\text { Penunjukan juru bicara perusahaan } \\
\text { dan prosedur penanganan media } \\
\text { belum ditentukan dan dijelaskan }\end{array}$ & $\begin{array}{lr}\text { Tinjau } & \text { ulang } \\
\text { Emergency } & \text { Response } \\
\text { Plan Manual } & \\
\end{array}$ & $\begin{array}{l}\text { ERP } \\
\text { Manual }\end{array}$ \\
\hline 6 & $\begin{array}{l}\text { Family } \\
\text { Assistance }\end{array}$ & $\begin{array}{l}\text { Panduan tentang pendekatan } \\
\text { organisasi untuk membantu korban } \\
\text { krisis atau organisasi pelanggan } \\
\text { belum ada. }\end{array}$ & $\begin{array}{lr}\text { Tinjau } & \text { ulang } \\
\text { Emergency } & \text { Response } \\
\text { Plan Manual } & \end{array}$ & $\begin{array}{l}\text { ERP } \\
\text { Manual }\end{array}$ \\
\hline 7 & $\begin{array}{l}\text { Post- } \\
\text { occurrence } \\
\text { review }\end{array}$ & $\begin{array}{l}\text { Tidak ada prosedur peninjauan } \\
\text { setelah krisis }\end{array}$ & $\begin{array}{lr}\text { Tinjau } & \text { ulang } \\
\text { Emergency } & \text { Response } \\
\text { Plan Manual } & \end{array}$ & $\begin{array}{l}\text { ERP } \\
\text { Manual }\end{array}$ \\
\hline 8 & $\begin{array}{l}\text { Drills or } \\
\text { Exercises }\end{array}$ & $\begin{array}{l}\text { Drills atau Latihan belum pernah } \\
\text { dilakukan }\end{array}$ & Pelaksanaan Latihan & $\begin{array}{l}\text { Simulasi } \\
\text { Emergency } \\
\text { Response } \\
\text { Plan }\end{array}$ \\
\hline
\end{tabular}

Tahapan selanjutnya, menentukan potensi resiko yang mugkin terjadi pada saat kegiatan praktek terbang dan selanjutnya dilakukan penilaian resiko. Dalam melakukan penilaian resiko berdasarkan dokumen Safety Management System Manual Jurusan Penerbang. Analisis ini dapat menjadi dasar untuk menentukan skenario dalam penanganan kondisi darurat.

\section{Identifikasi Bahaya (Hazard Identification)}

Identifikasi bahaya dilakukan pada setiap tahapan penerbangan dari mulai pengisian bahan bakar sampai dengan kembali mendarat pada landasan pacu.

Tabel 2

\begin{tabular}{|c|c|c|}
\hline ACTIVITY & HAZARD & CONSEQUENCES \\
\hline \multirow{4}{*}{ Refueling } & Lack of knowledge about refueling procedures & Engine off, Fire \\
\hline & Unavailability of fuel check equipment & Engine off, Fire \\
\hline & Lack of knowledge about refueling procedures & Emergency landing \\
\hline & Fuel spillage & People injury, Aircraft damage \\
\hline \multirow{4}{*}{$\begin{array}{l}\text { Standing } \\
\text { (Run Up / } \\
\text { Start } \\
\text { Engine } \\
\text { /Shut } \\
\text { Down) }\end{array}$} & Lack of knowledge and experience & Aircraft crash, people injury \\
\hline & Maintenance failure & Fire \\
\hline & Unavaibility of hearing protection & Hearing loss \\
\hline & Foreign Object Debris (FOD) & aircraft damage, people injury \\
\hline
\end{tabular}


Langit Biru: Jurnal Ilmiah Aviasi Vol. 14 No. 1 Februari 2021

ISSN (p) 1979-1534 ISSN (e) 2745-8695

\begin{tabular}{|c|c|c|}
\hline \multirow{3}{*}{ Taxi } & ATC/Flight crew Harsh accent - pronunciation & Runways excursion \\
\hline & Aircraft Marshaller is not licensed & Aircraft damage \\
\hline & Human error, unexperiences & $\begin{array}{l}\text { Collision with other aircraft, } \\
\text { Taxiway incursion }\end{array}$ \\
\hline \multirow{5}{*}{ Take off } & Cross wind & $\begin{array}{l}\text { Loss Of Control/Runway } \\
\text { Excursion }\end{array}$ \\
\hline & Maintenance failure & $\begin{array}{l}\text { Loss Of Control/Runway } \\
\text { Excursion }\end{array}$ \\
\hline & Birds on the maneuvering area & Bird strike/aircraft damaged \\
\hline & Wrong Take off configuration & Aircraft stall/crash \\
\hline & Wild animal & Aircraft damage \\
\hline \multirow{6}{*}{ En-route } & Bad weather & $\begin{array}{l}\text { Control Flight Into Terrain, Mid- } \\
\text { air collision, people injury }\end{array}$ \\
\hline & Traffic crowded & Mid air Collision \\
\hline & Maintenance failure & Loss position \\
\hline & Unfamiliar, unexperiences/Fatigue flight crews & Loss position \\
\hline & ATC/Flight crew Harsh accent - pronunciation & Mid air Collision \\
\hline & $\begin{array}{l}\text { Lack of knowledge, unexperiences/Fatigue flight } \\
\text { crews }\end{array}$ & $\begin{array}{l}\text { Control Flight into Terrain } \\
\text { (CFIT), Aircraft crash/multiple } \\
\text { fatalities, injuries }\end{array}$ \\
\hline \multirow{3}{*}{ Approach } & Bad weather & $\begin{array}{l}\text { Overshoot/Undershoot/runway } \\
\text { excursion }\end{array}$ \\
\hline & Crosswind & $\begin{array}{l}\text { Overshoot/Undershoot/runway } \\
\text { excursion }\end{array}$ \\
\hline & Unexperiences/Fatigue crews & $\begin{array}{l}\text { Overshoot/Undershoot/runway } \\
\text { excursion }\end{array}$ \\
\hline \multirow{4}{*}{ Landing } & Birds on the maneuvering area & Bird strike/aircraft damaged \\
\hline & Maintenance failure & $\begin{array}{l}\text { Overshoot/Undershoot/aircraft } \\
\text { damaged }\end{array}$ \\
\hline & Wet Runway & Runways excursion \\
\hline & Incorrect landing calculation & Runways excursion \\
\hline
\end{tabular}

2. Penilaian Resiko

Dari masing-masing resiko dan konsekuensi peneliti dan tim dari akan melakukan penilaian berdasarkan Severity dan Likelihood/Probalility yang telah tercantum dalam dokumen Safety Management System Manual Jurusan Penerbang. 
Analisis Emergency Response Plan (ERP) pada Kegiatan Praktek Terbang Taruna Jurusan Penerbang Sekolah Tinggi Penerbangan Indonesia Curug

Tabel 3 Severity Scale

\begin{tabular}{|c|c|}
\hline VALUE & DESCRIPTION \\
\hline 1 & $\begin{array}{l}\text { NEGLIGIBLE } \\
\text { - Little consequences }\end{array}$ \\
\hline 2 & $\begin{array}{l}\text { MINOR } \\
\text { - } \quad \text { Nuisance } \\
\text { - } \quad \text { Minor injury } \\
\text { - } \text { Minor damage }\end{array}$ \\
\hline 3 & $\begin{array}{l}\text { MAJOR } \\
\text { - A significant reduction in safety margins, a reducing in the ability of the operator to } \\
\text { cope with adverse operating conditions as a result of increase in workload, or as a } \\
\text { result of conditions impairing their efficiency. } \\
\text { - Loss of work injury } \\
\text { - More serious damage to equipment } \\
\text { - Major expense }\end{array}$ \\
\hline 4 & $\begin{array}{l}\text { HAZARDOUS } \\
\text { - A large reduction in safety margins, physical distress or a workload such that the } \\
\text { operator cannot be relied upon to perform their tasks accurately or completely } \\
\text { - Serious injury } \\
\text { - Major equipment damage } \\
\text { - Unacceptable expense }\end{array}$ \\
\hline 5 & $\begin{array}{l}\text { CATASTROPHIC } \\
\text { - Critical equipment destroyed } \\
\text { - } \quad \text { Fatalities } \\
\text { - } \quad \text { Extreme expense }\end{array}$ \\
\hline
\end{tabular}

Tabel 4 Probability/Likelihood Scale

\begin{tabular}{|c|l|}
\hline VALUE & \multicolumn{1}{c|}{ DESCRIPTION } \\
\hline $\mathbf{1}$ & Extremely Improbable: Almost inconceivable that the event will occur. \\
\hline $\mathbf{2}$ & Improbable: Very unlikely to occur (Instances have been recorded). \\
\hline $\mathbf{3}$ & Remote: Unlikely under existing conditions, but possible to occur (Has rarely occurred). \\
\hline $\mathbf{4}$ & Occasional: Likely to occur sometimes (Has occurred but infrequently) \\
\hline $\mathbf{5}$ & Frequent: Likely to occur many times (Has occurred frequently). \\
\hline
\end{tabular}

Table 5 Risk Assessment Matrix

\begin{tabular}{|c|c|c|c|c|c|}
\hline $\begin{array}{l}\text { SEVERITY } \longrightarrow \\
\text { PROBABILITY }\end{array}$ & $\begin{array}{c}\text { Catastrophic } \\
\text { (5) }\end{array}$ & $\begin{array}{l}\text { Hazardous } \\
\text { (4) }\end{array}$ & $\begin{array}{l}\text { Major } \\
\text { (3) }\end{array}$ & $\begin{array}{l}\text { Minor } \\
(2)\end{array}$ & $\begin{array}{l}\text { Negative } \\
\text { (1) }\end{array}$ \\
\hline Frequent (5) & 25 & 20 & 15 & 10 & 5 \\
\hline Likely (4) & 20 & 16 & 12 & 8 & 4 \\
\hline Occasional (3) & 15 & 12 & 9 & 6 & 3 \\
\hline Seldom (2) & 10 & 8 & 6 & 4 & 2 \\
\hline Unlikely (1) & 5 & 4 & 3 & 2 & 1 \\
\hline
\end{tabular}


Langit Biru: Jurnal Ilmiah Aviasi Vol. 14 No. 1 Februari 2021

ISSN (p) 1979-1534 ISSN (e) 2745-8695

Table 6 Criticality Scale

\begin{tabular}{|c|c|l|l|}
\hline Index & $\begin{array}{c}\text { Criticality } \\
\text { Level }\end{array}$ & \multicolumn{1}{|c|}{ Decisions and actions } \\
\hline $1-3$ & Acceptable & Acceptable. \\
\hline $4-14$ & $\begin{array}{c}\text { Tolerable } \\
\text { Region }\end{array}$ & $\begin{array}{l}\text { Acceptable based on cost benefit or risk mitigation. It might require } \\
\text { management decision. }\end{array}$ \\
\hline $15-25$ & $\begin{array}{c}\text { Intolerable } \\
\text { Region }\end{array}$ & $\begin{array}{l}\text { Unacceptable under existing circumstances. Management action } \\
\text { required. }\end{array}$ \\
\hline
\end{tabular}

Table 7 Result of Risk Assessment

\begin{tabular}{|c|c|c|c|c|c|c|c|}
\hline \multirow{2}{*}{ NO } & \multirow{2}{*}{$\begin{array}{c}\text { HAZARDOUS } \\
\text { SITUATION }\end{array}$} & \multirow{2}{*}{ CONSEQUENCES } & \multicolumn{4}{|c|}{ WITHOUT CONTROL } & \multirow{2}{*}{ MITIGATION } \\
\hline & & & $S$ & $L$ & & $R$ & \\
\hline \multirow[t]{5}{*}{1} & Refueling & & & & & & \\
\hline & $\begin{array}{l}\text { Improper } \\
\text { refueling }\end{array}$ & Engine off, Fire & 3 & 3 & 9 & $\begin{array}{l}\text { Tolerable } \\
\text { Region }\end{array}$ & $\begin{array}{l}\text { Standard } \\
\text { Operating } \\
\text { Procedure } \\
\text { (SOP), Training, } \\
\text { fire extinguisher }\end{array}$ \\
\hline & $\begin{array}{l}\text { Drum and label } \\
\text { contents are not } \\
\text { appropriate }\end{array}$ & Engine off, Fire & 3 & 3 & 9 & $\begin{array}{l}\text { Tolerable } \\
\text { Region }\end{array}$ & $\begin{array}{l}\text { Standard } \\
\text { Operating } \\
\text { Procedure } \\
\text { (SOP),Fuel check } \\
\text { equipment, fire } \\
\text { extinguisher }\end{array}$ \\
\hline & $\begin{array}{l}\text { Aircraft fuel } \\
\text { tank cover is } \\
\text { not locked } \\
\text { properly }\end{array}$ & Emergency landing & 4 & 1 & 4 & $\begin{array}{l}\text { Tolerable } \\
\text { Region }\end{array}$ & $\begin{array}{l}\text { Standard } \\
\text { Operating } \\
\text { Procedure } \\
\text { (SOP), } \\
\text { Supervision, } \\
\text { Checklist } \\
\end{array}$ \\
\hline & $\begin{array}{l}\text { Fuel spillage on } \\
\text { refueling area }\end{array}$ & $\begin{array}{l}\text { People injury, } \\
\text { aircraft damage }\end{array}$ & 2 & 1 & 2 & $\begin{array}{l}\text { Acceptabl } \\
e\end{array}$ & \\
\hline \multirow[t]{5}{*}{2} & $\begin{array}{lc}\text { Standing } & \text { (Run } \\
\text { Up / } & \text { Start } \\
\text { Engine } & \text { /Shut } \\
\text { Down) } & \\
\end{array}$ & & & & & & \\
\hline & $\begin{array}{l}\text { Improper use of } \\
\text { breaks }\end{array}$ & $\begin{array}{l}\text { Aircraft } \quad \text { crash, } \\
\text { People injury }\end{array}$ & 4 & 2 & 8 & $\begin{array}{l}\text { Tolerable } \\
\text { Region }\end{array}$ & $\begin{array}{l}\text { Training, } \\
\text { Supervision }\end{array}$ \\
\hline & $\begin{array}{l}\text { Clogging of oil } \\
\text { filters }\end{array}$ & Fire & 3 & 2 & 6 & $\begin{array}{l}\text { Tolerable } \\
\text { Region }\end{array}$ & $\begin{array}{l}\text { Routine } \\
\text { maintenance, fire } \\
\text { extinguisher }\end{array}$ \\
\hline & $\begin{array}{l}\text { Run up without } \\
\text { hearing } \\
\text { protection }\end{array}$ & Hearing loss & 2 & 4 & 8 & $\begin{array}{l}\text { Tolerable } \\
\text { Region }\end{array}$ & $\begin{array}{l}\text { Standard } \\
\text { Operating } \\
\text { Procedure } \\
\text { (SOP), Provide } \\
\text { hearing } \\
\text { protection } \\
\end{array}$ \\
\hline & $\begin{array}{l}\text { FOD on the run } \\
\text { up area }\end{array}$ & $\begin{array}{l}\text { Aircraft damage, } \\
\text { people injury }\end{array}$ & 3 & 2 & 6 & $\begin{array}{l}\text { Tolerable } \\
\text { Region }\end{array}$ & $\begin{array}{l}\text { Apron overlay, } \\
\text { sweeping FOD }\end{array}$ \\
\hline 3 & Taxi & & & & & & \\
\hline
\end{tabular}


Analisis Emergency Response Plan (ERP) pada Kegiatan Praktek Terbang Taruna Jurusan Penerbang Sekolah Tinggi Penerbangan Indonesia Curug

\begin{tabular}{|c|c|c|c|c|c|c|c|}
\hline \multirow{2}{*}{ NO } & \multirow{2}{*}{$\begin{array}{c}\text { HAZARDOUS } \\
\text { SITUATION }\end{array}$} & \multirow{2}{*}{ CONSEQUENCES } & \multicolumn{4}{|c|}{ WITHOUT CONTROL } & \multirow{2}{*}{ MITIGATION } \\
\hline & & & $S$ & $L$ & & $R$ & \\
\hline & $\begin{array}{l}\text { Flight crew } \\
\text { follow wrong } \\
\text { instruction/mis- } \\
\text { interpreted } \\
\text { from ATC } \\
\text { without check } \\
\text { and rechecking } \\
\end{array}$ & Runways excursion & 4 & 2 & 8 & $\begin{array}{l}\text { Tolerable } \\
\text { Region }\end{array}$ & $\begin{array}{l}\text { Recheck } \\
\text { Instruction/clear } \\
\text { ance, Read Back } \\
\text { instruction/clear } \\
\text { ance, IELP } \\
\text { training }\end{array}$ \\
\hline & $\begin{array}{l}\text { Aircraft } \\
\text { parking with an } \\
\text { unlicensed } \\
\text { marshaller } \\
\end{array}$ & Aircraft damage & 4 & 2 & 8 & $\begin{array}{l}\text { Tolerable } \\
\text { Region }\end{array}$ & $\begin{array}{l}\text { Training for } \\
\text { marshaller, } \\
\text { parking stand } \\
\text { settings }\end{array}$ \\
\hline & High speed taxi & $\begin{array}{l}\text { Collision } \\
\text { aircraft, } \\
\text { incursion }\end{array}$ & 4 & 2 & 8 & $\begin{array}{l}\text { Tolerable } \\
\text { Region }\end{array}$ & $\begin{array}{l}\text { Aircraft manual, } \\
\text { Refresher } \\
\text { training, warning } \\
\text { system, ATC } \\
\text { advises. }\end{array}$ \\
\hline \multirow[t]{6}{*}{4} & Take off & & & & & & \\
\hline & $\begin{array}{l}\text { Improper } \\
\text { techniques to } \\
\text { handle cross } \\
\text { wind take off } \\
\end{array}$ & $\begin{array}{l}\text { Loss } \quad \text { Of } \\
\text { Control/Runway } \\
\text { Excursion }\end{array}$ & 4 & 2 & 8 & $\begin{array}{l}\text { Tolerable } \\
\text { Region }\end{array}$ & $\begin{array}{l}\text { Simulator } \\
\text { Training, inform } \\
\text { by ATC }\end{array}$ \\
\hline & $\begin{array}{lr}\text { Lack } & \text { of } \\
\text { precheck } & \text { prior } \\
\text { departure }\end{array}$ & $\begin{array}{ll}\text { Loss } & \text { Of } \\
\text { Control/Runway } & \\
\text { Excursion }\end{array}$ & 4 & 2 & 8 & $\begin{array}{l}\text { Tolerable } \\
\text { Region }\end{array}$ & $\begin{array}{l}\text { Check list, } \\
\text { Supervision }\end{array}$ \\
\hline & $\begin{array}{l}\text { Aircraft take off } \\
\text { with bird in } \\
\text { surrounding }\end{array}$ & $\begin{array}{l}\text { Bird strike/aircraft } \\
\text { damaged }\end{array}$ & 4 & 1 & 4 & $\begin{array}{l}\text { Tolerable } \\
\text { Region }\end{array}$ & $\begin{array}{l}\text { Bird scaring } \\
\text { activities, } \\
\text { Windscreen } \\
\text { design standards, } \\
\text { Socialization } \\
\text { related rubbish } \\
\text { dump }\end{array}$ \\
\hline & 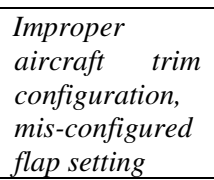 & Aircraft stall/crash & 5 & 2 & 10 & $\begin{array}{l}\text { Tolerable } \\
\text { Region }\end{array}$ & Check list \\
\hline & $\begin{array}{lr}\begin{array}{l}\text { Wild } \\
\text { enter }\end{array} & \text { animal } \\
\text { runway } & \text { the } \\
\end{array}$ & Aircraft damage & 4 & 2 & 8 & $\begin{array}{l}\text { Tolerable } \\
\text { Region }\end{array}$ & $\begin{array}{l}\text { Runway } \\
\text { inspection, } \\
\text { socialization }\end{array}$ \\
\hline \multirow[t]{4}{*}{5} & En-route & & & & & & \\
\hline & $\begin{array}{lr}\text { Flight } & \text { crews } \\
\text { decide } & \text { to } \\
\text { deviate } & \text { from } \\
\text { assigned } & \text { flight } \\
\text { plan } & \\
\end{array}$ & $\begin{array}{lr}\text { Control } & \text { Flight Into } \\
\text { Terrain, } & \text { Mid-air } \\
\text { collision, } & \text { people } \\
\text { injury }\end{array}$ & 5 & 2 & 10 & $\begin{array}{l}\text { Tolerable } \\
\text { Region }\end{array}$ & $\begin{array}{l}\text { TCAS, Weather } \\
\text { Radar, Simulator } \\
\text { training }\end{array}$ \\
\hline & $\begin{array}{l}\text { aircraft } \\
\text { outbound and } \\
\text { inbound using } \\
\text { same route }\end{array}$ & Mid air Collision & 5 & 2 & 10 & $\begin{array}{l}\text { Tolerable } \\
\text { Region }\end{array}$ & $\begin{array}{l}\text { Slot time, } \\
\text { Recheck } \\
\text { Instruction/clear } \\
\text { ance }\end{array}$ \\
\hline & $\begin{array}{l}\text { Aircraft unable } \\
\text { to set the } \\
\text { navigation } \\
\text { route }\end{array}$ & Loss position & 3 & 3 & 9 & $\begin{array}{l}\text { Tolerable } \\
\text { Region }\end{array}$ & $\begin{array}{l}\text { Refreshing } \\
\text { course, Rest time } \\
\text { management, } \\
\text { routine } \\
\text { maintenance }\end{array}$ \\
\hline
\end{tabular}


Langit Biru: Jurnal Ilmiah Aviasi Vol. 14 No. 1 Februari 2021

ISSN (p) 1979-1534 ISSN (e) 2745-8695

\begin{tabular}{|c|c|c|c|c|c|c|c|}
\hline \multirow{2}{*}{ NO } & \multirow{2}{*}{$\begin{array}{c}\text { HAZARDOUS } \\
\text { SITUATION }\end{array}$} & \multirow{2}{*}{ CONSEQUENCES } & \multicolumn{4}{|c|}{ WITHOUT CONTROL } & \multirow{2}{*}{ MITIGATION } \\
\hline & & & $S$ & $L$ & & $\boldsymbol{R}$ & \\
\hline & $\begin{array}{l}\text { Pilot unable to } \\
\text { identify his } \\
\text { current } \\
\text { position } \\
\text { (disorientation) }\end{array}$ & Loss position & 3 & 3 & 9 & $\begin{array}{l}\text { Tolerable } \\
\text { Region }\end{array}$ & $\begin{array}{l}\text { Refreshing } \\
\text { course, Rest time } \\
\text { management, }\end{array}$ \\
\hline & $\begin{array}{l}\text { Flight crew } \\
\text { follow wrong } \\
\text { instruction/mis- } \\
\text { interpreted } \\
\text { from ATC } \\
\text { without check } \\
\text { and rechecking }\end{array}$ & Mid air Collision & 5 & 2 & 10 & $\begin{array}{l}\text { Tolerable } \\
\text { Region }\end{array}$ & $\begin{array}{l}\text { TCAS, Recheck } \\
\text { Instruction/clear } \\
\text { ance, Read Back } \\
\text { instruction/clear } \\
\begin{array}{l}\text { ance, } \\
\text { training }\end{array}\end{array}$ \\
\hline & $\begin{array}{l}\text { Improper } \\
\text { handling } \\
\text { aircraft on bad } \\
\text { weather } \\
\text { condition }\end{array}$ & $\begin{array}{l}\text { Control Flight into } \\
\text { Terrain } \quad(\text { CFIT }), \\
\text { Aircraft } \\
\text { crash/multiple } \\
\text { fatalities, injuries }\end{array}$ & 5 & 3 & 15 & $\begin{array}{l}\text { Intolerabl } \\
\text { e Region }\end{array}$ & $\begin{array}{l}\text { Utilizer human } \\
\text { aided technology } \\
\text { (weather radar, } \\
\text { etc.). Encourage } \\
\text { dispatch to } \\
\text { obtain/communic } \\
\text { ate weather } \\
\text { information, Rest } \\
\text { time management }\end{array}$ \\
\hline \multirow[t]{4}{*}{6} & Approach & & & & & & \\
\hline & $\begin{array}{l}\text { Flight crew } \\
\text { can't see the } \\
\text { runway }\end{array}$ & $\begin{array}{l}\text { Overshoot/Undersho } \\
\text { ot/runway excursion }\end{array}$ & 5 & 1 & 5 & $\begin{array}{l}\text { Tolerable } \\
\text { Region }\end{array}$ & $\begin{array}{l}\text { Weather Radar, } \\
\text { Simulator } \\
\text { training, }\end{array}$ \\
\hline & $\begin{array}{l}\text { Aircraft } \\
\text { landing under } \\
\text { crosswind } \\
\text { condition }\end{array}$ & $\begin{array}{l}\text { Overshoot/Undersho } \\
\text { ot/runway excursion }\end{array}$ & 5 & 2 & 10 & $\begin{array}{l}\text { Tolerable } \\
\text { Region }\end{array}$ & $\begin{array}{l}\text { Simulator } \\
\text { training, } \quad \text { Go } \\
\text { round }\end{array}$ \\
\hline & $\begin{array}{l}\text { Approach } \\
\text { speed too high }\end{array}$ & $\begin{array}{l}\text { Overshoot/Undersho } \\
\text { ot/runway excursion }\end{array}$ & 4 & 4 & 16 & $\begin{array}{l}\text { Intolerabl } \\
\text { e Region }\end{array}$ & $\begin{array}{lr}\begin{array}{l}\text { Aircraft } \\
\text { reduction, }\end{array} & \text { speed } \\
\text { time } & \\
\text { management, } \\
\text { checklist, } \\
\text { round }\end{array}$ \\
\hline \multirow[t]{5}{*}{7} & Landing & & & & & & \\
\hline & $\begin{array}{lr}\text { Aircraft } & \\
\text { landing with } \\
\text { bird } \quad \text { in } \\
\text { surrounding }\end{array}$ & $\begin{array}{l}\text { Bird strike/aircraft } \\
\text { damaged }\end{array}$ & 4 & 1 & 4 & $\begin{array}{l}\text { Tolerable } \\
\text { Region }\end{array}$ & $\begin{array}{l}\text { Bird scaring } \\
\text { activities, } \\
\text { Aircraft speed } \\
\text { reduction, } \\
\text { Windscreen } \\
\text { design standards } \\
\end{array}$ \\
\hline & $\begin{array}{l}\text { Aircraft } \\
\text { breaking is not } \\
\text { work properly } \\
\end{array}$ & $\begin{array}{l}\text { Overshoot/Undersho } \\
\text { ot/aircraft damaged }\end{array}$ & 5 & 2 & 10 & $\begin{array}{l}\text { Tolerable } \\
\text { Region }\end{array}$ & $\begin{array}{l}\text { Precheck before } \\
\text { flight, }\end{array}$ \\
\hline & $\begin{array}{l}\text { Aircraft } \\
\text { landing under } \\
\text { wet runway }\end{array}$ & Runways excursion & 5 & 1 & 5 & $\begin{array}{l}\text { Tolerable } \\
\text { Region }\end{array}$ & $\begin{array}{l}\text { Inform by } A T C, \\
\text { Simulator } \\
\text { training }\end{array}$ \\
\hline & $\begin{array}{l}\text { Mis-configured } \\
\text { flap setting }\end{array}$ & Runways excursion & 5 & 3 & 15 & $\begin{array}{l}\text { Intolerabl } \\
\text { e Region }\end{array}$ & $\begin{array}{l}\text { Simulator } \\
\text { training, }\end{array}$ \\
\hline
\end{tabular}

Dari hasil Hazard Identification dan Risk Assesment and Mitigation terdapat 29 hazardous situation yang dapat menjadi dasar dalam penentuan 
Analisis Emergency Response Plan (ERP) pada Kegiatan Praktek Terbang Taruna Jurusan Penerbang Sekolah Tinggi Penerbangan Indonesia Curug

prosedur yang akan tercantum dalam Emergency Response Plan Manual serta dapat menjadi skenario dalam pelaksanaan simulasi penanganan keadaan darurat.

Peneliti melakukan review dan prosedur tambahan sesuai dengan regulasi nasional dan internasional. Dalam mengkaji Emergency Response Plan Manual, peneliti juga melakukan diskusi dengan beberapa pihak yang berpengalaman dalam menangani kondisi darurat maupun yang terlibat dalam Tim Tanggap Darurat. Serta dilakukan kajian terhadap beberapa literatur dari Rencana Darurat Bandara Budiarto dan Standart Operational Procedure (SOP) tentang keadaan darurat di Airnav Budiarto.

\section{Kesimpulan}

1. Emergency Response Plan Manual saat ini perlu dilakukan peningkatan/ penyempurnaan sesuai dengan kompleksitas di Jurusan Penerbang Sekolah Tinggi Penerbangan Indonesia Curug.

2. Untuk menguji prosedur yang telah tertuang dalam Emergency Response Plan Manual, perlu dilakukan table top excercise dan simulasi skala penuh.

3. Hasil dari Hazard Identification dan Risk Assesment and Mitigation terdapat 29 identifikasi bahaya yang selanjutnya dapat menjadi dasar penentuan prosedur yang terdapat dalam Emergency Response Plan Manual

\section{Daftar Pustaka}

Budiarto Airport. (2016). Budiarto Airport Emergency Plan Document. Jakarta.
Civil Air Navigation Services Organisation. (2015). CANSO Emergency Response Planning Guide.

Copa Airlines. (2015). Emergency Manual.

Directorate General of Civil Aviation Indonesia. (2015). KP 479 , Instructions and Procedures for Handling Airport Emergencies.

Directorate General of Civil Aviation Indonesia. (2016). Pedoman Teknis Operasional Peraturan Keselamatan Penerbangan Sipil Bagian 139 -16 (Advisory Circular Civil Aviation Safety Regulation Part 139 - 16) Pedoman Penyusunan Dokumen Rencana Penanggulangan Keadaan Darurat Bandar Udara.

Directorate General of Civil Aviation Indonesia. (2017). Civil Aviation Safety Regulation Part 830 on Aircraft Accident and Serious Incident Investigation Procedures. Jakarta.

Federal Emergency Management Agency. (n.d.). Community Emergency Response Team Drills and Exercises. Retrieved 2018, from https://www.fema.gov/medialibrary/assets/documents/27997

Gian Prima Yogi., A. R. (2016). Emergency Response Plan Garuda Indonesia. Jurnal Ilmiah Program Studi Hubungan Masyarakat .

GMF. (2014, September ). The Importance of Emergency Response Plan. Pengetahuan dan Informasi Safety PENITY 
Langit Biru: Jurnal Ilmiah Aviasi Vol. 14 No. 1 Februari 2021

ISSN (p) 1979-1534 ISSN (e) 2745-8695

(Persuasif,Informatif,Naratif),

pp. 6-8.

Indonesia Civil Aviation Institute (Pilot

School Certificate 141-001).

(2017). Safety Management

System Manual .

Indonesia Civil Aviation Institute (Pilot

School Certificate 141-001).

(2017). Standard Operating

Procedure Base Training.

International Civil Aviation

Organization. (1991). Doc. 9173

Part 7 Airport Emergency

Planning. Canada: Secretary

General.

International Civil Aviation

Organization. (2013). Doc. 9859

Safety Management Manual

(SMM). Canada: Secretary

General.

International Civil Aviation

Organization. (2013). Doc. 9973

Manual on Assistance to Aircarft

Accident Victims and their

Families. Canada: Secretary

General.

International Civil Aviation

Organization. (2013). ECCAIRS

Aviation 1.3.0.12 VL for AttrID:

391 - Event Phases.

Ministry of Transportation, Republic of Indonesia. (2017). PM 31 Organization and Working Procedure of STPI. Jakarta.

Ministy of Transportation, Republic of Indoensia . (2017). PM 62 about Safety Management System. Jakarta.

The Florida Department of Transportation . (n.d.). Aviation Emergency Response

Guidebook. 